\title{
Проявления интеллектуальной дифференциации в уровне и структуре гражданской идентичности студентов столичного и провинциального вузов
}

\author{
Маргарита К. Акимова', Елена И. Горбачева², Светлана В. Персиянцева ${ }^{1,3^{*}}$ \\ 1 Российский государственный гуманитарный университет (РГГУ), г. Москва, \\ Российская Федерация \\ 2 Калужский государственный университет им. К. Э. Циолковского, г. Калуга, \\ Российская Федерация \\ ${ }^{3}$ Психологический институт Российской академии образования, г. Москва, Российская \\ Федерация \\ *E-mail: perssvetlana@yandex.ru
}

\begin{abstract}
Аннотация
Ввеление. ПреАставлен сравнительный анализ показателей интел^ектуального развития и гражАанской иАентичности. Описана вариативность интемлектуального развития в соотношении с различными уровнями гражАанской иАентичности у стуАентов, обучающихся в разных социокультурных среАовых условиях. Новизна исслеАования: получены новые данные - о взаимосвязи между уровнем принятия и специорикой иерархии мичностных черт, характеризующих социальный капита^, и уровнем и структурой интелмекта инАивиАов, различающихся социокультурными условиями.
\end{abstract} Методы. В разделе описываются метолики: 1) Аля Аиагностики уровня интемлекта «Тест Умственного развития взрослых» (ТУРВ), разработанный на основе концепции социально-психологического норматива (СПН); 2) А^я изучения гражАанской ИАентичности - проективная метоАика «Аиагностика гражАанской иАентичности». Залания методики распределены по следующим шкалам: 1) отношение к правам этнических меньшинств; 2) отношение к правам сексуальных меньшинств; 3) отношение к либеральным ценностям; 4) отношение к политическим правам; 5) отношение к правам обездоленных; 6) отношение к правам миц с ограниченными возможностями; 7) отношение к России (Аанная шкала имеет отношение к патриотизму, характеризуя отношение граждан к государству, в котором они проживают, и его месту в мире).

Результаты. Аоказано, что чем выше уровень интеллектуального развития, тем более редлексивно критическое отношение студентов к происходящим событиям в стране. Высокоинтел^ектуальные студенты ценят ^ичную ответственность и своболу, позитивно относятся к правам меньшинств, к правовым орормам защиты чести и Аостоинства, стремятся формировать оценочную позицию в отношении к миру, используя разнообразную информацию, полученную из разных источников. 
ОбсужАение результатов. Аелается вывоА, что в условиях Московского социума интемлект способствует позитивному отношению стуАентов к ценностям либерального характера и усиливает их причастность к Аемократическим преобразованиям в России. В провинциальном социуме с повышением уровня интемлектуального развития у студентов возрастает уровень признания прав национальных и этнических меньшинств.

\section{КАючевые слова}

ценности гражАанского общества, гражАанская илентичность, согласованность гражАанских ценностей, интелмектуальная Аиффреренциация, уровень интелмектуального развития, региональная социокультурная среда, когнитивный механизм, социокультурный ресурс, ценностное символическое поле

\section{Основные положения}

- методическая процедура исследования гражданской идентичности базируется на трех (представленных ниже) эмпирически верисрицируемых положениях; - от аккумулированных инАивиАом норм зависит его ценностный выбор в конкретной социокультурной среде, которая созАается различными институтами и фрормирует ценностное символическое поле, воздействующее на находящихся В НеМ ИНАИВИАОВ;

опыт социализации, накопленный, с оАной стороны, «спонтанно», с Аругой стороны, с помощью специально организованного («реактивного», по терминологии ^.С. Выготского) процесса в ходе образования, позволяет инАивиАу ориентироваться в гражАанской сорере;

- когнитивный механизм (соотношение инАивиАуального опыта и социокультурной среды) обеспечивает наращивание социокультурного ресурса, что, в свою очередь, Аает возможность инАивиАу критично анализировать и оценивать поступающую информацию, требования социокультурной среды.

\section{Для цитирования}

Акимова М. К., Горбачева Е.И., Персиянцева С.В. Проявления интеллектуальной дифференциации в уровне и структуре гражданской идентичности студентов столичного и провинциального вузов // Российский психологический журнал. - 2018. - Т. 15, № 1. - C. 24-45. DOI: 10.21702/rpj.2018.1.2 


\title{
Intellectual Differentiation in the Level and Structure of Civil Identity in Students Studying at Moscow and Regional Higher Education Institutions
}

\author{
Margarita K. Akimova', Elena I. Gorbacheva ${ }^{2}$, Svetlana V. Persiyantseva ${ }^{1,3^{*}}$ \\ ${ }^{1}$ Russian State University for the Humanities, Moscow, Russian Federation \\ ${ }^{2}$ Tsiolkovsky Kaluga State University, Kaluga, Russian Federation \\ ${ }^{3}$ Psychological Institute, Russian Academy of Education, Moscow, Russian Federation \\ *Correspondence author. E-mail: perssvetlana@yandex.ru
}

\begin{abstract}
Introduction. This paper presents a comparative analysis of intellectual development and civil identity. Students studying at different socio-cultural environments demonstrate intellectual variability in relation to different levels of civil identity. The study provides new data on the relationship among the level of acceptance, personal traits characterizing social capital, and the structure and level of intelligence in individuals with different socio-cultural conditions.
\end{abstract}

Methods. The level of intelligence was measured using the Test of Adults' Mental Development (TAMD), which relied on the concept of a socio-psychological standard (SPS). The Diagnosis of Civil Identity projective technique was employed for studying civil identity. The technique included the following scales: (a) attitude towards the rights of ethnic minorities; (b) attitude towards the rights of sexual minorities; (c) attitude towards liberal values; (d) attitude towards political rights; (e) attitude towards the rights of the underprivileged; (f) attitude towards the rights of disabled persons; (g) attitude towards Russia in terms of patriotism (citizens' attitude towards the state they live in).

Results. A higher level of intellectual development determined students' reflexive and critical attitude towards events in the country. Students with a high level of intellectual development (a) appreciated personal responsibility and freedom, (b) had a positive attitude towards the rights of ethnic minorities and legal protection of honor and dignity, and (c) evaluated the world on the basis of information from different sources. Discussion. In Moscow social medium intelligence contributes to students' positive attitude towards liberal values and enhances their participation in democratic transformations in Russia. A higher level of intellectual development determines students' recognition of the rights of national and ethnic minorities in a regional social medium.

\section{Keywords}

values of civil society, civil identity, consistency of civil values, intellectual differentiation, 


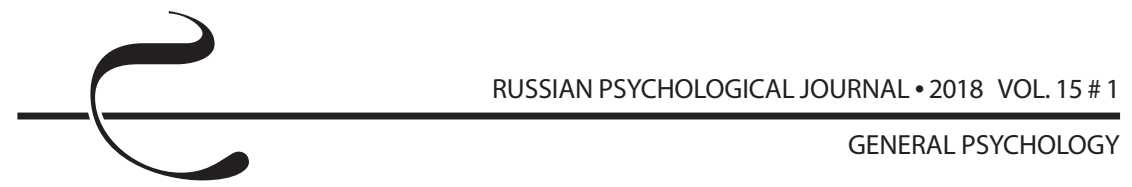

level of intellectual development, regional socio-cultural environment, cognitive mechanism, socio-cultural resource, value symbolic field

\section{Highlights}

- The following three propositions underlie a methodological procedure for studying civil identity.

- The adopted standards determine the individual's value choices in a specific sociocultural environment; this environment, created by various institutions, forms a value symbolic field affecting the individuals inside of it.

- Socialization experience, accumulated both spontaneously and purposefully, ensures individuals' orientation in the civil sphere.

- The cognitive mechanism (relationship between individual experience and sociocultural environment) increases a socio-cultural resource; this, in turn, enables individuals to critically analyze the information received and the socio-cultural environment.

\section{For citation}

Akimova M. K., Gorbacheva E. I., Persiyantseva S.V. Intellectual Differentiation in the Level and Structure of Civil Identity in Students Studying at Moscow and Regional Higher Education Institutions. Rossiiskii psikhologicheskii zhurnal - Russian Psychological Journal, 2018, V. 15, no. 1, pp. 24-45 (in Russian). DOI: 10.21702/rpj.2018.1.2

Original manuscript received 01.12.2017

\section{Введение}

Структурные и культурные изменения, переживаемые Россией на протяжении последних десятилетий, определили возрастание роли гражданской идентичности в самосознании личности, отвечающем вызовам современной реальности. С появлением новых объектов идентификации (сетевое сообщество, множество пересекающихся локальных групп, субкультур и др.) идентификационное пространство стремительно расширяется, а плюралистичность данного пространства, отражаясь в неопределенности культурных нормативов, приводит к тому, что в сознании россиян стирается «разделительная черта» между позитивным оценочным фоном восприятия социальных норм и его негативным фоном. Подобная аномия в современном российском социуме проявляется в парадоксальном сочетании признания ценности демократических свобод и апатичного отношения к социальным институтам, призванным защищать эти свободы, позитивного восприятия нормативов общественного служения и доминирования прагматических установок на фоне снижения нравственнокультурных ограничителей [1,2]. 
Любая идентичность приобретается в процессе социализации, являясь ее устойчивым продуктом и результатом согласования между личностными смыслами и значимыми характеристиками общества [3, 4]. В процессе социализации происходит соотнесение индивидом себя с обществом во всех социокультурных измерениях, к которым относятся язык, менталитет, мировоззрение, культурные, социально-политические ценности и нормы поведения $[5,6]$.

Сущностные характеристики гражданской идентичности обнаруживаются в противопоставлении общинного и общественного типов идентификаций. Первый из этих типов характеризуется включенностью в социальные отношения, основанной на аффективном чувстве принадлежности к коллективу, на силе традиции и культурного наследия. Это тип, для которого характерно доминирование «мы-идентификации». Второй тип коллективных идентичностей проявляется в социальных отношениях, основанных на рационально мотивированных ценностях и приверженности им как универсальным правилам социальной жизни [7]. Именно эта особенность гражданской идентичности позволяет индивиду преодолеть избыточность давления множества идентичностей - конфессиональной, этнической, профессиональной, семейной, клановой, сетевой, - с их собственными нормативами социального блага и локальными солидарностями, и реализовать ценности, которые применяются «независимо от связи с членами своей группы» [8, с. 31].

Гражданская идентичность не предопределяется ни традицией, ни местом проживания или рождения, ни статусными позициями, а складывается на основе выбора и синтеза ценностей $[9,10,11]$. Ее можно рассматривать как осознание принадлежности к структурам гражданского общества, опирающееся на его гуманистические ценности и значимость группового объединения на основе этих ценностей.

Идентификации со структурами гражданского общества происходят как под влиянием реального поведения его членов, жизненной практики, так и под воздействием систем образования и воспитания $[12,13,14,15,16]$. С этой точки зрения гражданская идентичность является проективной формой идентичности, для которой, по замечанию М. Кастельса, характерно то, что «социальные акторы, на основе доступного им культурного материала, строят новую идентичность, которая переопределяет их положение в обществе и направлена на преобразование всей социальной структуры» [см. 17, с. 6].

Актуализация гражданских ценностей для самоопределения и самоидентификации предполагает оперирование представлением об особом социуме «граждан», не имеющим четко очерченных границ. Ведь для понимания равенства людей с позиции универсального характера их гражданских прав следует отказаться от доступного обыденному суждению заключения, что 
люди не равны друг другу и не могут рассматриваться изолированно друг от друга. Здесь уже требуется анализ поведения индивида, помысленного максимально абстрактно, вне его включенности в конкретные сообщества, и действующего в соответствии в универсальными правилами, обязательными для принятия и применения всеми - и «своими», и «чужими» группами. Только таким образом понимаемые индивиды и могли быть проинтерпретированы как «равные в своих гражданских правах» [18, с. 97-112; 19, с. 47-58].

Будучи личностным феноменом, гражданская идентичность формируется на определенной мировоззренческой основе и поэтому является своеобразной интеграцией системы ценностей, которые функционируют в гражданском обществе. Принятие или отрицание, репрезентация и интерпретация ценностей гражданского общества, их категоризация и осознание должны быть опосредованы уровнем интеллектуального развития человека [20].

Планируя исследование, авторы опирались на принципы дифференциально-психологического подхода, который применительно к специфике принятия позитивных ценностей и практик гражданского общества означает анализ условий и факторов их формирования, выявление структуры гражданской идентичности и ее соотношения с ассоциированными чертами индивидуальности. Еще один принцип дифференциально-психологического исследования заключается в том, что среди указанных черт выявляют, прежде всего, существенные, отделяя их от несущественных. Внутренними существенными причинами, объясняющими вариативность присвоения ценностей гражданского общества и их проявлений в гражданских практиках, можно считать интеллектуальные различия.

Обоснование методической процедуры исследования гражданской идентичности и специфики ее выраженности у испытуемых с разными интеллектуальными характеристиками базируется на трех эмпирически верифицируемых положениях. Первое из них исходит из того, что индивид осуществляет ценностный выбор только в определенной социокультурной среде, в которой представлены различного рода нормативные предписания, в том числе гражданского содержания. Эта среда, создаваемая различными институтами, формирует ценностное символическое поле, воздействующее на находящихся в нем индивидов. Второе положение заключается в том, что индивид должен обладать определенным опытом социализации - интернализированными в ходе образования знаниями и способами действия, позволяющими ему ориентироваться в гражданской сфере, различать представленные в публичном пространстве ценностные альтернативы и выражать свое отношение к ним. Третье положение указывает на то, что существует особый когнитивный механизм, обеспечивающий соотнесение социокультурной среды и индивидуального опыта наращивания социокультурного ресурса, который 
обеспечивает восприятие, понимание, оценку поступающей информации, дает индивиду возможность осуществить анализ и оценку средовых факторов, в том числе актуальных и перспективных требований социокультурной среды, установить причинно-следственные отношения, характеризующие влияние личности на процессы, происходящие в социуме. Таким механизмом является интеллект. Иными словами, чтобы понять сущность гражданской идентичности как осознанной идентификации с ценностями и практиками гражданского общества, необходимо знать, в какой социокультурной среде находится индивид, каким он обладает социокультурным ресурсом, в какой мере он способен провести мыслительную обработку поступающей информации, т. е. какой уровень интеллектуального развития им достигнут. Данная методическая процедура получила подтверждение в рамках исследования по проекту 14-06-00658 «Ценности и практики гражданского поведения как функция интеллектуальной дифференциации», осуществленного при финансовой поддержке РГНФ.

\section{Методы}

В качестве эмпирической базы исследования использовались данные изучения уровня гражданской идентичности и образующей ее структуры гражданских ценностей в соотношении с показателями интеллектуального развития и его вариативности у студентов, обучающихся в средах с разным социокультурным ресурсом - в Российском гуманитарном государственном университете (РГГУ, г. Москва) и в Калужском государственном университете им. К.Э. Циолковского (КГУ, г. Калуга). В московскую выборку вошли студенты-психологи, средний возраст - 21 год, разброс 19-22 года (168 человек). Калужскую выборку составили студенты, обучающиеся по психолого-педагогическому и социогуманитарному направлениям, средний возраст - 20,7 лет, разброс от 18 до 22 лет (154 человека). Общий объем выборки составил 252 человека.

Для изучения гражданской идентичности применялась исследовательская методика проективного типа (авторы М. К. Акимова, Е.И. Горбачева). Методика разработана на основе нормативного подхода к личности и индивидуальности и выделения нормативных требований к тем сторонам личностного развития индивидов, которые описываются как гражданское самосознание. Представленный в ней конструкт «гражданская идентичность» получил такое операциональное определение: поддержка других в их отличиях и признание их гражданских прав, осознание важности устранения проблем, связанных с неравенством отдельных социальных групп, приверженность индивида целям демократических институтов, убежденность в необходимости позитивных изменений в своей стране. Стимульный материал методики включает 27 рисунков, представляющих ситуации социального взаимодействия, 


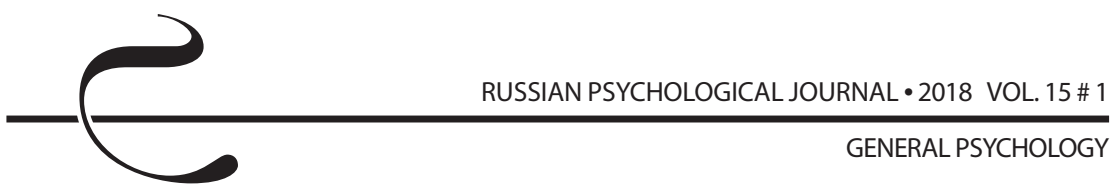

отношение к которым и их интерпретация указывают на принятие или непринятие ценностей гражданского общества. На переднем плане каждой картинки нарисованы два персонажа, один из которых комментирует изображенные ситуации. С другим персонажем участник исследования должен себя идентифицировать и отреагировать на комментарий, данный его собеседником. За каждый ответ начисляется от -2 до 2 баллов в зависимости от активности занимаемой позиции обследуемого, морально-правового или прагматического обоснования данной позиции, позитивной или негативной оценки анализируемых ситуаций нарушения гражданских прав и свобод.

Задания методики распределены по семи шкалам, объединяющим ситуации, в которых обнаруживаются следующие ценности гражданского общества: права этнических меньшинств, права сексуальных меньшинств, либеральные права, политические права, права экономически обездоленных, права лиц с ограниченными возможностями здоровья, отношение к демократическим преобразованиям в России. При обработке подсчитывались данные по каждой шкале и общий показатель, фиксирующий уровень сформированности гражданской идентичности. Отрицательные значения по шкалам и методике в целом свидетельствовали о негативной, антигражданской идентичности.

Диагностика уровня интеллекта осуществлялась с помощью теста умственного развития взрослых (ТУРВ), разработанного коллективом авторов под руководством М.К. Акимовой. Тест опирается на концепцию социальнопсихологических нормативов (СПН) [21, 22], согласно которой психическое развитие индивидов происходит под воздействием системы требований, предъявляемых обществом к каждому своему члену. Тест предназначен для оценки функционирования интеллекта взрослых в возрасте от 18 до 50 лет. Тест состоит из семи субтестов: «Словарь», «Осведомленность», «Умозаключения», «Классификация», «Аналогии», «Обобщение», «Числовые ряды».

О достигнутом уровне интеллектуального развития студентов могли свидетельствовать сформированные у них умения: давать определения научно-культурным понятиям, т. е. формулировать в явной и сжатой форме их основное содержание; понимать и классифицировать жизненные ситуации, заключенные в пословицах, находить в них общее и различное; мыслить по аналогии на материале научно-культурных понятий; находить общее и специфичное в понятиях, выделять те существенные признаки, по которым они могут быть объединены; понимать закономерности, выраженные знаковой символикой, и оперировать ею, производить умозаключения в качестве неотъемлемого компонента и повседневного, и профессионального мышления взрослого человека. Измерению подлежала также общая информированность обследуемого, его осведомленность как мера «врастания в культуру» и присвоения доминирующей в ней информации. 
Основными методами получения данных являлись: методические процедуры установления корреляционной связи между уровнями принятия и согласованности ценностей гражданского общества и показателями интеллектуального развития студентов, обучающихся в разных региональных социокультурных средах; метод контрастных групп (группы с выраженной интеллектуальной дифференциацией), предусматривающий сравнительный анализ показателей присвоения конкретных видов гражданских ценностей и их структуры, уровней гражданской идентичности и интеллектуального развития. Результаты диагностики, полученные в объединенной выборке и субвыборках, включались в систему дескриптивной статистики (среднее, минимальные и максимальные значения, стандартное отклонение). При анализе полученных показателей применялся корреляционный анализ по методу Спирмена, позволяющий уточнить предположение о зависимости степеней идентификации с ценностями гражданского общества от уровня интеллектуального развития во всех сравниваемых группах. Статистическая обработка результатов проводилась с помощью программы «SPSS Statistics 19.0».

\section{Результаты}

Анализ среднегрупповых баллов по тесту ТУРВ показывает, что студенческая выборка оказалась неоднородной по интеллектуальному развитию. Как и ожидалось, более высокие тестовые баллы продемонстрировали студенты, обучающиеся в московском вузе $(M=66,10)$. В этой подгруппе интеллектуальная дифференциация достаточно выражена и представлена низкими средними, средневысокими и высокими показателями интеллекта. В калужской студенческой выборке дифференциация уровней интеллекта в основном проходила по линии низких, средних и средневысоких показателей $(M=54,73)$, а среднегрупповой показатель интеллекта значимо отличался от полученного в московской студенческой выборке. При этом важно отметить, что московская сувыборка оказалась менее однородной в интеллектуальном отношении; об этом свидетельствовали величина стандартного отклонения (SD $=15,46)$ и разброс индивидуальных результатов (от 13 до 99 баллов). В калужской выборке эти показатели менее демонстративны: $\mathrm{SD}=14,17$ и разброс от 19 до 85 соответственно.

Результаты, полученные с помощью методики «Гражданская идентичность», указали на неоднородность степени причастности гражданским ценностям, как в объединенной студенческой выборке, так и в региональных субвыборках. Результаты идентификаций с объектами и явлениями гражданской сферы варьировались от достаточно полного их принятия до явного отрицания их значимости для самоидентификации в российском социуме. Более высокие показатели присвоения ценностей гражданского общества были получены 


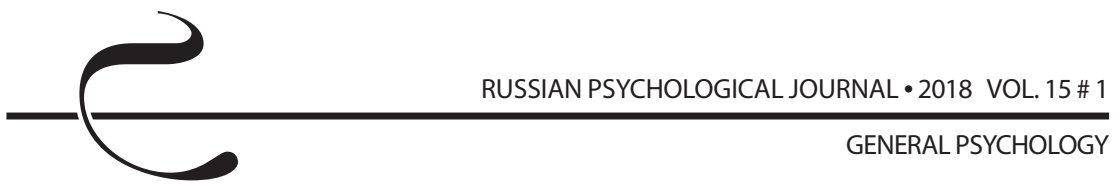

у московских студентов ( $M=11,71 ; \mathrm{SD}=11,81)$. Меньшую приверженность этим ценностям продемонстрировали студенты калужского вуза $(\mathrm{M}=9,71 ; \mathrm{SD}=10,24)$.

Таким образом, и калужские и московские студенты в равной мере проявили готовность следовать ценностям правовой справедливости, реализуемой по отношению к лицам с ограниченными возможностями и к экономически обездоленным группам населения. Существенно не различаются региональные субвыборки в признании права России на демократический выбор. Молодые люди, хотя и признавали необходимость демократических преобразований в нашем государстве, все же указывали как на непреодолимую данность, что правовые нормы и правила поведения в российском социуме отличаются от европейских («у нас так было и всегда будет»), и изменить уклад общественной жизни в нашей стране не представляется возможным. В отличие от московских студентов их калужские сверстники в меньшей степени проявили свою солидарность с теми, кто готов отстаивать политические права, учитывать своеобразие образа жизни этнических и сексуальных меньшинств. Если представители московской субвыборки часто отмечали, что мигранты должны иметь равные права с русскими, в том числе на работу, и выказали уверенность, что приезжие способны лучше справляться со своими обязанностями («они не пьют», «у них имеются налаженные связи с производителями», «они не ленятся»), то в калужской субвыборке лишь немногие из ее представителей признавали права представителей нетитульных наций на свободное проживание, перемещение по стране и равный доступ к труду. Результаты по шкале «Права сексуальных меньшинств» показали, что московские студенты с большей определенностью считают, что лица с нетрадиционной сексуальной ориентацией требуют толерантного отношения в российском обществе и нуждаются в поддержке в проявлении их отличий и в реализации их гражданских прав. Такие ответы редко встречались у студентов, обучающихся в провинциальном вузе.

Обнаружились противоречия в отношениях к либеральным ценностям в сопоставляемых субвыборках. Независимо от социокультурного ресурса сред, в которых проживали и обучались студенты, все они склонны поддерживать такие ценности, как свободный доступ к информации, цивилизованное устройство повседневной жизни, благоприятная окружающая среда. Вместе с тем приверженность таким либеральным правам, как право на выражение своего мнения, право на обсуждение общественных планов и диалог с властью, право на свободное проявление общественной активности, оказалась не свойственна обследуемым студентам. Вместе с тем, в уровне приверженности либеральным правам студенты московского вуза продемонстрировали отчетливую тенденцию к более высоким показателям по сравнению со студентами провинциального вуза. 
Результаты соотношения степени принятия гражданских ценностей, уровня гражданской идентичности и уровня интеллектуального развития посредством корреляционного анализа (по методу Спирмена) подтвердили роль интеллектуальной дифференциации в характере присвоения гражданских ценностей.

Анализ корреляционных связей и уровней их значимости выявил, что в объединенной студенческой выборке было получено $25 \%$ значимых связей между показателями приверженности гражданским ценностям разного содержания и уровнем развития интеллекта и отдельных интеллектуальных действий. В большей степени оказались связанными с интеллектом признание прав сексуальных меньшинств $\left(r_{s}=0,13 ; p=0,02\right)$, отношение к либеральным правам $\left(r_{s}=0,14 ; p=0,01\right)$ и правам лиц с ОВ3 $\left(r_{s}=0,11 ; p=0,04\right)$, а также общий показатель приверженности ценностям гражданского общества $\left(r_{s}=0,13\right.$; $p=0,02)$. Наибольший вклад во взаимосвязь интеллекта и гражданской идентичности внесли такие компоненты интеллектуального развития, как осведомленность, классификация, обобщение и общий показатель интеллектуального развития.

В московской студенческой выборке случаи взаимосвязи принимаемых гражданских ценностей и интеллектуального развития были выявлены лишь для отдельных видов ценностей и интеллектуальных действий: в частности, признание прав детей с ОВ3 значимо коррелировало с осведомленностью $\left(r_{s}=0,24 ; p=0,02\right)$, а приверженность демократическим преобразованиям в России связана на уровне тенденции с умением воспроизводить умозаключения $\left(r_{s}=0,17 ; p=0,09\right)$. Немногочисленные случаи зависимости степени приверженности ценностям гражданского общества от интеллекта выявлены в калужской выборке. Отношение к правам сексуальных меньшинств и правам людей с ОВ3 оказались достоверно связаны с интеллектуальным умениями установления аналогии $\left(r_{s}=0,16, p=0,05\right.$ и $\left.r_{s}=0,17, p=0,04\right)$ и реконструкции структуры умозаключения $\left(r_{s}=0,19\right.$, $p=0,04$ и $r_{s}=0,16, p=0,05$ соответственно). Принятие ценности защиты политических прав на уровне тенденции коррелировало с установлением аналогий $\left(r_{s}=0,14 ; p=0,07\right)$ и умением производить обобщения $\left(r_{s}=0,12\right.$; $p=0,09)$. Полученные данные указывают на то, что соотношение уровня интеллектуального развития и гражданской идентичности по-разному проявилось в группах, обучающихся в разных региональных социокультурных средах. Этот факт должен был получить дальнейшее подтверждение в сопоставлении контрастных групп, в которых различия по интеллекту проявятся с большей демонстративностью.

В подгруппах верхнего ( $M=86,60)$ и нижнего квартилей $(M=45,52)$ результатов ТУРВ у студентов московского вуза выделены лишь отдельные 


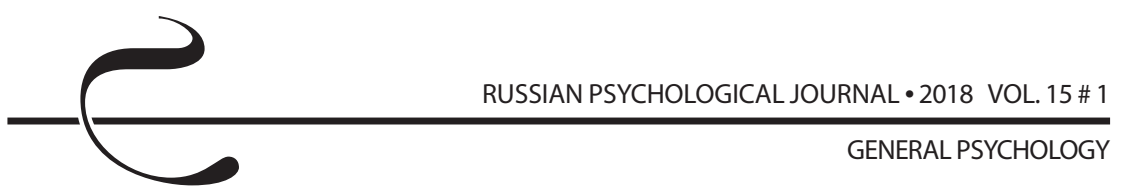

случаи значимой связи между уровнем интеллекта и степенью принятия ценностей гражданского общества: у низкоинтеллектуальных студентов (нижний квартиль показателей интеллектуального развития) выявлено 9\% значимых связей между указанными переменными, в группе высокоинтеллектуальных студентов доля таких связей существенно не отличалась (7,8\%). В подгруппе нижнего квартиля показателей интеллектуального развития в калужской субвыборке $(M=37,75)$ выявлено только 6,25\% значимых связей между показателями интеллектуального развития и степенью приверженности ценностям гражданского общества. Это связи между осведомленностью, принятием прав лиц с ОВ3 и общем уровнем гражданской идентичности $\left(r_{s}=0,34\right.$, $p=0,03$ и $_{\mathrm{s}}=0,31, \mathrm{p}=0,05$ соответственно). В подгруппе верхнего квартиля $(\mathrm{M}=71,85)$ доля значимых корреляционных связей между измеряемыми переменными была также невелика и составила всего 7,8\%. Больший вклад в эту зависимость в данной подгруппе вносила уже не осведомленность, а интеллектуальное умение выявлять противоречие в умозаключениях, сформированность которого на уровне тенденции коррелировала с приверженностью либеральным правам $\left(r_{s}=0,29 ; p=0,06\right)$ и общим уровнем гражданской идентичности.

С усилением интеллектуальной дифференциации посредством выделения контрастных групп с $10 \%$ самых низких и $10 \%$ высоких результатов ТУРВ зависимость формируемой гражданской идентичности от уровня интеллектуального развития проявилась с большей определенностью. В московской субвыборке с возрастанием интеллекта $(\mathrm{M}=86,2)$ увеличилось количество корреляционных связей (26\%), и изменилась их теснота. В этой группе (группа 90 процентиля) выявлены взаимосвязи между принятием ценности политических прав и участия в политическом процессе, а также отношением к свободам и правам личности с умением давать определения научно-культурным понятиям (субтест «Словарь») - и общим уровнем интеллектуального развития $\left(r_{s}=0,76, p=0,000 ; r_{s}=0,35, p=0,04\right.$ соответственно), между присвоением ценностей защиты прав сексуальных меньшинств, прав лиц с ОВЗ и общим уровнем интеллектуального развития $\left(r_{s}=0,36, p=0,03 ; r_{s}=0,29, p=0,06\right)$, между признанием права на милосердие и поддержку для экономически обездоленных и умением производить умозаключения $\left(r_{s}=0,62 ; p=0,001\right)$, между отношением к демократическим преобразованиям в России и интеллектуальным умением классификации $\left(r_{s}=0,45 ; p=0,02\right)$.

В группе 90 процентиля калужской субвыборки $(M=73,0)$ выявлено $37 \%$ случаев значимой корреляционной связи между интеллектом и принятием гражданских ценностей. Заметнее обозначилась избирательность в составе связанных с интеллектом принимаемых ценностных нормативов. 
Так, у высокоинтеллектуальных студентов проявилась значимая связь между степенью принятия прав этнических и сексуальных меньшинств и уровнем интеллектуального развития $\left(r_{s}=0,50, p=0,05 ; r_{s}=0,48, p=0,07\right.$ соответственно). В группе низкоинтеллектуальных студентов корреляционная зависимость между интеллектом и гражданскими ценностями имела следующую специфику: с ним значимо соотносились милосердие к обездоленным и правовая защита лиц с ОВ3 $\left(r_{s}=0,33 ; p=0,05\right)$. В подгруппе низкоинтеллектуальных студентов $(M=35,0)$ доля таких связей невысока и составляет $11 \%$.

Зависимость причастности к гражданским ценностям от интеллектуальной дифференциации в разных региональных социокультурных средах приобретает качественную специфику. В условиях московского социума интеллект способствует позитивному отношению к ценностям либерального характера и усиливает приверженность к демократическим преобразованиям в России. В провинциальном социуме с ростом интеллекта формируется такая важная составляющая гражданской идентичности, как рефлексивная солидарность, способствующая признанию прав этнических и сексуальных меньшинств.

Роль интеллектуальной дифференциации в вариативности принятия гражданских ценностей и сформированной гражданской идентичности проявилась в увеличении меры согласованности уровней принятия гражданских ценностей.

Если в группе нижнего квартиля показателей интеллектуального развития в объединенной студенческой выборке выявлено $53 \%$ случаев перекрестных статистически достоверных связей между гражданскими ценностями разного содержания, то в подгруппе верхнего квартиля число таких связей возрастает и приближается к 68\%. В субвыборке московских студентов (в подгруппе высокоинтеллектуальных студентов) выявлено 59\% перекрестных значимых связей между гражданскими ценностями, тогда как в подгруппе нижнего квартиля количество таких связей составило $26 \%$. У московских студентов эта тенденция также получила подтверждение: в подгруппе высокоинтеллектуальных студентов имели место $46 \%$ перекрестных значимых связей, в группе низкоинтеллектуальных студентов доля взаимосвязанных гражданских ценностей составила только $21 \%$. В калужской студенческой выборке $57 \%$ перекрестных связей между принимаемыми гражданскими ценностями выявлено в подгруппе верхнего квартиля, в группе нижнего квартиля таких связей оказалось $28 \%$. Полученные данные указывают на то, что с ростом уровня интеллекта гражданская идентичность начинает функционировать как внутренне согласованная и целостная система идентификаций личности с ценностями гражданской сферы. 


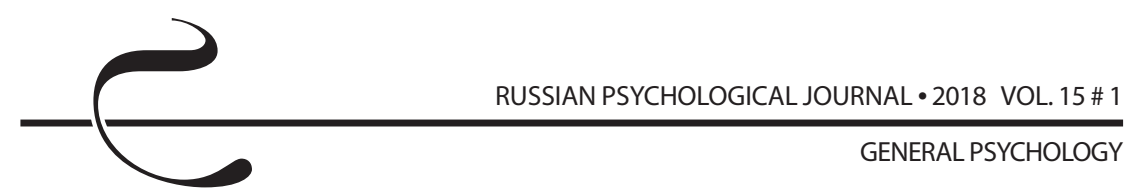

\section{Обсуждение результатов}

Выявленные факты, свидетельствующие как о различиях, так и некоторых общих тенденциях в проявлениях интеллектуальной дифференциации в составе и уровнях принимаемых гражданских ценностей, полученные в субвыборках московских и калужских студентов, нуждаются в интерпретации.

В современной социальной феноменологии утверждается, что значительную роль в жизни людей играют «повседневные стили жизни», выражающие ценности и интересы, регулирующие поведение людей в привычной для них среде [23, 24]. Культура повседневности отдельного региона - это особый образ жизни, слагающийся из ценностей, обычаев, традиций, этических норм и т. д. Общий опыт социализации в данном случае играет решающую роль не только в генезисе тех или иных ценностей, но и в их усвоении, изменении значений, соответствующих тем или иным социокультурным нормативам. Москву среди других регионов выделяет не только уровень, но и качество социально-экономического развития, вызванное активным вовлечением в процессы глобализации, формирования современной информационной среды, межрегионального и внешнего миграционного потоков и культурного обмена. Вместе с тем в условиях мегаполиса усиливается неготовность его жителей принять и успешно осваивать новую социальную ситуацию. По данным многочисленных социологических опросов [25, 26, 27, 28], значительная часть учащейся молодежи в г. Москве выражает откровенное неприятие мигрантов, высказывается за введение жестких ограничений на въезд и пребывание в России лиц нерусской национальности. Эти проявления нетерпимости особенно ярко проявляются в массовом сознании жителей провинции, где противопоставление «мы и они» питается как многовековой традицией обособленного проживания, так и современными реалиями региональной жизни, в частности, усилением конкуренции в условиях ограниченных экономических ресурсов.

Противоречивый характер связи гражданской идентичности и уровня интеллектуального развития, расхождение между приверженностью базовым гражданским ценностям и готовностью ими руководствоваться в оценке и интерпретации социальных ситуаций, выявленные как в московской, так и в калужской субвыборках, подтверждают значение надындивидуальных источников знаний, запечатленных в культуре общества и различных его групп. Отношение к гражданским ценностям и идентификация с ними могут соотноситься с этими источниками в большей степени, чем с собственной интеллектуальной активностью индивида. Следует учесть, что многие представления об обществе, поступающие к индивиду от различных социальных институтов - семьи, школы, средств массовой информации - усваиваются 
им в «готовом виде», не подвергаясь какой-либо когнитивной модификации и мыслительной обработке. В ситуации ценностной неопределенности и когнитивного дефицита по поводу воспринимаемых ситуаций гражданского действия установки, присвоенные в доступных для индивида средовых условиях, активизируются и используются в качестве средств житейской интерпретации правовых, нравственных, политических ценностей гражданской сферы. Иначе говоря, индивид в ситуации ценностного выбора может проявить избирательное отношение к ценностям, на которые ориентировались значимые для него агенты социализации, и его представления о общественном благе, гражданском долге, правах и свободе личности будут опираться на готовые суждения, распространенные в его окружении.

Отношение к гражданским ценностям может осуществляться посредством актуализации дисперсных аффективных и поведенческих установок или же выражаться в эмоциональном восприятии ценностей без их рационального анализа. По сути, это предориентационная форма ценностного выбора. Высшей же его формой является идентифицирующая ориентация, означающая, что «человек сознательно отождествляет себя с какими-то системами ценностей, неформальными или институционализированными типами воззрений и политического поведения» [29, с. 20].

В условиях обогащенной и наполненной гражданскими смыслами социокультурной среды вуза студент приучается использовать гражданские ценности как своего рода «символический капитал», воспринимая их как «полезную» и «хорошую» традицию. Такие случаи имел в виду П. Бурдьё, когда отмечал, что «практики, порожденные габитусом и управляемые прошлыми условиями формирования порождающего их принципа, заранее адаптированы к объективным условиям всякий раз, когда условия, в которых функционирует габитус, идентичны или похожи на условия, в которых он сформировался. Соответствие объективным условиям достигается наилучшим и непосредственным образом, порождая при этом полнейшую иллюзию целенаправленности или, что сводится к тому же, иллюзию саморегулирующегося механизма» [30, с. 121; 31]. Ценностное отношение здесь является фактически реактивным и безальтернативным, поскольку оно базируется на нерефлексируемой установке, которая субъективно воспринимается как единственно возможная в данной ситуации. Тогда как подлинный выбор и рациональная интерпретация гражданских ценностей предполагают целенаправленную оценку различных вариантов социального действия. Лишь когда включение интеллекта создает проблемное поле гражданских действий и смыслов, индивид начинает не только замечать явления и объекты гражданской сферы, но и осуществлять практики взаимодействия с ними. 


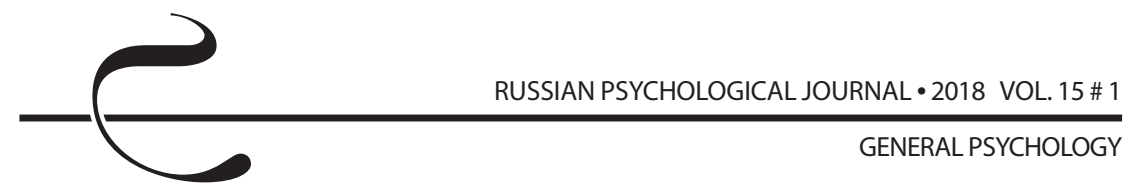

\section{Заключение}

Данные соотношения уровней интеллектуального развития и степени принятия гражданских ценностей, дополненные сравнительным анализом дисперсии индивидуальных показателей в группах высокоинтеллектуальных и низкоинтеллектуальных студентов, подтверждают, что различия в отношениях студенческой молодежи к ценностным нормативам гражданского общества определяются уровнем интеллектуального развития. От этой когнитивной характеристики зависит как непосредственное понимание содержания ценностного выбора в гражданской сфере, так и его рациональной мотивации, объясняющей смысл применяемых практик социальной активности. Формирование соответствующих гражданской идентичности отношений к свободе и достоинству личности, правам меньшинств и готовности их защищать требуют от личности развитых мыслительных процессов, умений понимать происходящие в обществе события, оценивать их последствия и осознавать собственную активную позицию как гражданина.

Студенты с низким уровнем интеллектуального развития достоверно отличаются от своих высокоинтеллектуальных сверстников индифферентным или негативным отношением к политическим правам и правам меньшинств, неприятием правовых форм защиты чести и достоинства, отказом от открытого проявления гражданской позиции во взаимодействии с властными и общественными институтами. В структуре гражданской идентичности низкоинтеллектуальных студентов умеренное принятие ценностей свободы личности функционирует независимо от признания прав этнических и сексуальных меньшинств, готовности отстаивать свои политические права и отношения к демократическим преобразованиям в России.

У высокоинтеллектуальных студентов позитивные идентификации с разными по содержанию гражданскими ценностями складываются в единую взаимосвязанную структуру. Гражданская идентичность высокоинтеллектуальных студентов проявляется в рефлексивно-критическом отношении к миру, имеющем в своей основе стремление получать и опираться в своих оценках на разнообразную информацию, а также сознательность, свободу и ответственность личности. При высоком уровне интеллектуального развития возможны дифференциация и согласование гражданских ценностей, что позволяет выйти на новый уровень их анализа и обобщения, абстрагироваться от второстепенных, связанных с «близкой» социокультурной средой, правил и традиций социального действия и сосредоточить свое внимание на ценностях более высокого порядка, характеризующих гражданское общество.

Проявляясь в позитивной гражданской идентичности, интеллект обеспечивает представление о социальной реальности как о «единстве в многообразии», что открывает возможности для конструктивного взаимодействия с носителями социально-групповых, этнических и иных различий. 


\section{Литература}

1. Петухов В. В. Гражданская активность как альтернатива антидемократическому тренду российской политики // ПОЛИС. Политические исследования. - 2013. - № 5. - С. 87-99.

2. Юревич А. В. Психологическое состояние современного российского общества: новые оценки // Вопросы психологии. - 2015. - № 2. - С. 32-45.

3. Эриксон Э. Идентичность: юность и кризис. - М. : Прогресс, 2006. $240 \mathrm{c}$.

4. Иванова Н.Л., Мазилова Г.Б. Гражданская идентичность и формирование гражданственности // Ученые записки Педагогического института СГУ им. Н. Г. Чернышевского. Серия Психология. Педагогика. - 2010. - Т. 3, № 4 (12). - С. 11-20.

5. Акимова М. К., Горбачева Е. И., Козлова В. Т. Нормативная концепция диагностики индивидуальности // Век психологии. К 100-летию Психологического института Российской академии образования. - СПб. : Нестор-История, 2012. - С. 630-654.

6. ТлеужА. Х. Конструирование российской коллективной идентичности. М. : Социально-гуманитарные знания, 2011. - 224 с.

7. Филиппова Е. И. Найти себя. Конструирование идентичностей в постсоветской России // Диалоги об идентичности и мультикультурализме. - М. : Изд-во Института этнологии и антропологии им. Н. Н. Миклухо-Маклая РАН, 2004. - С. 155-167.

8. Гофман А. Б. Концептуальные подходы к анализу социального единства // Социологические исследования. - 2015. - № 11. - С. 29-36.

9. Акимова М. К. Условия и факторы, влияющие на формирование феномена гражданской идентичности // Психология сознания: истоки и перспективы изучения : материалы XIV Международных чтений памяти Л. С. Выготского / под ред. В. Т. Кудрявцева. - М. : Изд-во РГГУ, 2013. - Т. 1. - С. 72-78.

10. Акимова М. К., Персиянцева С. В. Факторы, определяющие формирование гражданской идентичности // Теоретические и прикладные вопросы образования и науки : сборник научных трудов по материалам Международной научно-практической конференции. - Тамбов:ООО «Консалтинговая компания Юком», 2014. - Часть 3. - С. 10-15.

11. Акимова М. К., Персиянцева С. В. Роль гражданской идентичности в структуре социального капитала // Гуманитарные научные исследования. 2015. - № 6 (46). - C. 16-23. - URL: http://human.snauka.ru/2015/06/11812 (дата обращения: 11.01.2018).

12. Асмолов А. Г. Как будем жить дальше? Социальные эффекты образовательной политики // Лидеры образования. - 2007. - № 6. - С. 4-10. 
13. Асмолов А. Г. Стратегия социокультурной модернизации образования: на пути к преодолению кризиса идентичности // Вопросы образования. - 2008. - № 1. - С. 65-86.

14. Kahne J. E., Sporte S. E. Developing Citizens: The Impact of Civic Learning Opportunities on Students' Commitment to Civic Participation // American Educational Research Journal. - 2008. - Vol. 45, Issue 3. - P. 738-766. DOI: 10.3102/0002831208316951

15. Tajfel H., Turner J. C. The social identity theory of intergroup behavior // Austin W. G., Worchel S. Psychology of Intergroup Relations. - Chicago : Nelson-Hall, 1986. - 2nd ed. - P. 7-24.

16. Usborne E., De La Sablonniere R. Toward a social psychology of social change: insights from Identity Process Theory // Identity Process Theory / R. Jaspal, G. M. Breakwell (Eds.). - Cambridge : Cambridge University Press, 2012. P. 203-221. DOI: 10.1017/CBO9781139136983.015

17. Castells M. The Power of Identity. Economy, Society and Culture.-Cambridge, Mass : Blackwell, 1997. - P. 4-16.

18. Копосов Н. Е. Логика демократии // Новое литературное обозрение. 2003. - № 64. - C. 97-112. - URL: http://magazines.russ.ru/nlo/2003/64/ kolos7.html (дата обращения: 27.02.2018).

19. РезникЮ.М. Человек в гражданском обществе: проблема идентичности // Человек вчера и сегодня: междисциплинарные исследования. - М. : Изд-во ИФ РАН, 2008. - Вып. 1. - С. 47-57. - URL: https://iphras.ru/uplfile/ root/biblio/chel/Chel_1.pdf (дата обращения: 27.02.2018).

20. KanazawaS. Why Liberals and Atheists Are More Intelligent // Social Psychology Quarterly. -2010. - Vol.73, Issue 1.-P.33-57.DOI: 10.1177/0190272510361602

21. Гуревич К. М. Дифференциальная психология и психодиагностика. Избранные труды. - СПб. : Питер, 2012. - 612 с.

22. Акимова М. К., Горбачева Е. И. Нормативный подход к диагностике: обоснование и разработка методики // Теоретическая и экспериментальная психология. - 2013. - Т. 6, № 2. - С. 45-56.

23. Розенберг Н. В. Трансформация стиля повседневной жизни в современном городском пространстве // Аналитика культурологии. - 2008. № 11. - С. 263-265.

24. Розенберг Н. В. Повседневная культура региона как основа стабильности российского общества // Известия высших учебных заведений. Поволжский регион. Гуманитарные науки. - 2009. - № 4. - С. 49-53.

25. Зайончковская Ж., Полетаев Д., Флоринская Ю., Доронина К. Мигранты глазами москвичей // Демоскоп Weekly. - 2014. - № 605-606. - C. 1-28. URL: http://www.demoscope.ru/weekly/2014/0605/s_map.php\#1 (дата обращения: 27.02.2018). 
26. Воробьева И. В. Отношение к трудовым мигрантам в сознании студенческой молодежи Москвы // Вестник Российского государственного гуманитарного университета. Серия «Философия. Социология. Искусствоведение». - 2015. - № 7 (150). - С. 85-89.

27. Михайлова Е. Мигранты в России: эффект присутствия // Всероссийский центр изучения общественного мнения. - 2016. - Пресс-выпуск № 3254. - URL: http://old2.wciom.ru/index.php?id=459\&uid=115969 (дата обращения: 27.02.2018).

28. Леконцев И. Эмиграционные настроения россиян - 2017 // Всероссийский центр изучения общественного мнения. - 2017. - Пресс-выпуск №3411. URL: https://wciom.ru/index.php?id=236\&uid=116299 (дата обращения: 27.02.2018).

29. Дилигенский Г. Г. Социально-политическая психология : Учебное пособие для вузов. - М. : Новая школа, 1996. - 2-е изд. - 352 с.

30. Бурдьё П. Практический смысл / пер. с фр. А. Т. Бикбова, К. Д. Вознесенской, С. Н. Зенкина, Н. А. Шматко. - СПб. : Алетейя ; М. : Изд-во Института экспериментальной социологии, 2001. - 562 с.

31. Bourdieu P., Boltanski L. La production de l'idéologie dominante. - Paris : Demopolis, 2008. - 157 p.

\section{References}

1. Petukhov V. V. Civil activity as an alternative to the antidemocratic trend in Russian politics. POLIS. Politicheskie issledovaniya - Polis. Political Studies, 2013, no. 5, pp. 87-99 (in Russian).

2. Yurevich A. V. Psychological state of modern Russian society: new evaluation. Voprosy psikhologii, 2015, no. 2, pp. 32-45 (in Russian).

3. Erikson E. Identity: youth and crisis (Russ. ed.: Erikson E. Identichnost': yunost' i krizis. Moscow, Progress Publ., 2006. 240 p.).

4. Ivanova N. L., Mazilova G. B. Civil identity and the formation of civic consciousness. Uchenye zapiski Pedagogicheskogo instituta SGU im. N. G. Chernyshevskogo. Seriya Psikhologiya. Pedagogika - Scientific Notes by Pedagogical Institute of Saratov State University named after N. G. Chernyshevsky. Psychology. Pedagogy, 2010, V. 3, no. 4 (12), pp. 11-20 (in Russian).

5. Akimova M. K., Gorbacheva E. I., Kozlova V. T. The normative concept of diagnosing individuality. In: Rubtsov V. V. (ed.) Vek psikhologii. K 100-letiyu Psikhologicheskogo instituta Rossiiskoi akademii obrazovaniya [The century of psychology: Celebrating the 100th anniversary of the Psychological Institute of the Russian Academy of Education]. St. Petersburg, Nestor-History Publ., 2012, pp. 630-654. 
6. Tleuzh A. Kh. Konstruirovanie rossiiskoi kollektivnoi identichnosti [Constructing Russian collective identity]. Moscow, Sotsial'no-gumanitarnye znaniya Publ., 2011. 224 p.

7. Filippova E. I. Finding yourself: Constructing identities in post-Soviet Russia. In: Le Coadic R., Filippova E. (eds.) Dialogi ob identichnosti i mul'tikul'turalizme [Dialogues on identity and multiculturalism]. Moscow, Institute of Anthropology and Ethnography Publ. 2004, pp. 155-167.

8. Gofman A. B. Conceptual approaches to the analysis of social integrity. Sotsiologicheskie Issledovaniia - Sociological Studies, 2015, no. 11, pp. 29-36.

9. Akimova M. K. Conditions and factors influencing the formation of civil identity. In: Kudryavtsev V. T. (ed.) Psikhologiya soznaniya: istoki i perspektivy izucheniya: materialy XIV Mezhdunarodnykh chtenii pamyati L. S. Vygotskogo [Psychology of consciousness: origins and prospects of research. The 14th International readings in memory of L. S. Vygotsky]. Moscow, Russian State University for the Humanities Publ., 2013, V. 1, pp. 72-78.

10. Akimova M. K., Persiyantseva S. V. Faktory, opredelyayushchie formirovanie grazhdanskoi identichnosti [Factors for the formation of civil identity]. Teoreticheskie i prikladnye voprosy obrazovaniya i nauki : sbornik nauchnykh trudov po materialam Mezhdunarodnoi nauchno-prakticheskoi konferentsii [Proc. the International Theoretical and Practical Conference "Theoretical and applied problems of education and science"]. Tambov, Konsaltingovaya kompaniya Yukom Publ., 2014, Part 3, pp. 10-15.

11. Akimova M. K., Persiyantseva S. V. Civil identity in the structure of social capital. Humanities scientific researches, 2015, no. 6 (46), pp. 16-23. Available at: http://human.snauka.ru/2015/06/11812 (Accessed 11 January 2018).

12. Asmolov A. G. How do we live forth? Social effects of educational policy. Lidery obrazovaniya - Leaders of Education, 2007, no. 6, pp. 4-10 (in Russian).

13. Asmolov A. G. The strategy of socio-cultural modernization of education: on the way to overcoming the identity crisis. Voprosy obrazovania-Educational Studies, 2008, no. 1, pp. 65-86 (in Russian).

14. Kahne J. E., Sporte S. E. Developing citizens: The impact of civic learning opportunities on students' commitment to civic participation. American Educational Research Journal, 2008, V. 45, Issue 3, pp. 738-766. DOI: $10.3102 / 0002831208316951$

15. Tajfel H., Turner J. C. The social identity theory of intergroup behavior. In: Austin W. G., Worchel S. (eds.) Psychology of intergroup relations. Chicago, Nelson-Hall, 1986, pp. 7-24.

16. Usborne E., De La Sablonniere R. Toward a social psychology of social change: insights from identity process theory. In: R. Jaspal, G. M. Breakwell (eds.). 
Identity process theory. Cambridge, Cambridge University Press, 2012, pp. 203-221. DOI: 10.1017/CBO9781139136983.015

17. Castells M. The power of identity. Economy, Society and Culture. Cambridge, Mass, Blackwell, 1997, pp. 4-16.

18. Koposov N. E. The logic of democracy. Novoe literaturnoe obozrenie - New literary observer, 2003, no. 64, pp. 97-112. Available at: http://magazines. russ.ru/nlo/2003/64/kolos7.html (Accessed 27 February 2018).

19. Reznik Yu. M. A man in civil society: the problem of identity. Chelovek vchera i segodnya: mezhdistsiplinarnye issledovaniya - The Man Yesterday and Today: an Interdisciplinary Study, Moscow, 2008, V. 1, pp. 47-57. Available at: https:// iphras.ru/uplfile/root/biblio/chel/Chel_1.pdf (Accessed 27 February 2018).

20. Kanazawa S. Why liberals and atheists are more intelligent. Social Psychology Quarterly, 2010, V. 73, Issue 1, pp. 33-57.DOI: 10.1177/0190272510361602

21. Gurevich K. M. Differentsial'naya psikhologiya i psikhodiagnostika. Izbrannye trudy [Differential psychology and psychodiagnostics: selected works]. St. Petersburg, Piter Publ., 2012. 612 p.

22. Akimova M. K., Gorbacheva E. I. Normative approach to diagnostics: Development and validation of the technique. Teoreticheskaya i eksperimental'naya psikhologiya - Theoretical and Experimental Psychology, 2013, V. 6, no. 2, pp. 45-56 (in Russian).

23. Rozenberg N. V. Transformation of the style of everyday life in contemporary urban space. Analitika kul'turologii - Analytics of Culturology, 2008, no. 11, pp. 263-265 (in Russian).

24. Rozenberg N. V. Everyday culture of the region as the basis for stability of Russian society. Izvestiya vysshikh uchebnykh zavedenii. Povolzhskii region. Gumanitarnye nauki - News from Higher Educational Institutions: Volga Region. Humanities, 2009, no. 4, pp. 49-53 (in Russian).

25. Zaionchkovskaya Zh., Poletaev D., Florinskaya Yu., Doronina K. Migrants through the eyes of Muscovites. Demoscope Weekly, 2014, no. 605-606, pp. 1-28. Available at: http://www.demoscope.ru/weekly/2014/0605/s_map. php\#1 (Accessed 27 February 2018).

26. Vorob'eva I. V. Attitudes towards labor migrants among Moscow youth. Vestnik Rossiiskogo gosudarstvennogo gumanitarnogo universiteta. Seriya: Filosofiya. Sotsiologiya. Iskusstvovedenie, 2015, no. 7 (150), pp. 85-89 (in Russian).

27. Mikhailova E. Migrants in Russia: presence effect. Vserossiiskii tsentr izucheniya obshchestvennogo mneniya - Russian Public Opinion Research Center, 2016, press release no. 3254. Available at: http://old2.wciom.ru/ index.php?id=459\&uid=115969 (Accessed 27 February 2018).

28. Lekontsev I. Emigration moods in Russians: 2017. Vserossiiskii tsentr izucheniya obshchestvennogo mneniya - Russian Public Opinion Research 
Center, 2016, press release no. 3411. Available at: https://wciom.ru/index. php?id=236\&uid=116299 (Accessed 27 February 2018).

29. Diligenskii G. G. Sotsial'no-politicheskaya psikhologiya [Socio-political psychology]. Moscow, Novaya shkola Publ., 1996. 352 p.

30. Bourdieu P. Practical reason (Russ. ed.: Burd'e P. Prakticheskii smysl. St. Petersburg, Aleteiya Publ., 2001. 562 p.).

31. Bourdieu P., Boltanski L. La production de l'idéologie dominante. Paris, Demopolis, 2008. 157 p. 